\title{
Viral Genetics
}

National Cancer Institute

\section{Source}

National Cancer Institute. Viral Genetics. NCI Thesaurus. Code C19111.

The branch of science concerned with the means and consequences of viral transmission and generation of the components of biological inheritance. 